\title{
Host-parasite relationships between Porichthys porosissimus (Pisces) and cestode larvae of the Scolex group
}

\author{
S. GUAGLIARDO, D. TANZOLA, C. SCHWERDT, N. GALEANO
}

\begin{abstract}
Laboratorio de Patología de Organismos Acuáticos, Departamento de Biología, Bioquímica y Farmacia, Universidad Nacional del Sur, San Juan 670, 8000 Bahía Blanca, Argentina, E-mail: rtanzola@uns.edu.ar
\end{abstract}

\begin{abstract}
Summary
Larvae of tetraphyllidean cestodes have been recorded in several species of marine teleosts. However, little is known on parasite-host interactions. In view of this, the present study aims at i) determining the localization sites of a larval type, belonging to the Scolex group, in the digestive tract mucose; ii) describing the anatomo-pathological features of the larval lesions produced; and iii) evaluating the potential effect of parasite intensity on the body condition of the host. Our findings reveal that parasitic charges were more intense in the second portion of the digestive tract. In the area of contact between the parasite and the epithelium a compressive atrophy of the cells was observed with a marked lowering and disappearance of the epithelial layer. The condition factor of the samples analyzed was significantly affected by infection intensity, thus revealing an adverse effect on the growth and physical condition of the host.
\end{abstract}

Keywords: Tetraphyllidea; Porichthys porosissimus; Pathology; Scolex group

\section{Introduction}

Marine teleosts are intermediate hosts for different morphotypes of tetraphyllidean metacestode larvae. The latter have been described in the literature under different names such as Scolex pleuronectis Muëller 1787, Scolex polymorphus Rudolphi 1819, Scolex de Bavay (Szidat 1969), metacestodes (Wardle \& Mc Leod, 1952), plerocercoids (Chervy, 2002), and cercoids (Rocka, 2003, 2006). Most of the records of these parasites quantify their presence as members of parasite assemblages in different host species but make no reference to host-parasite interactions. In fact, to elucidate the role of helminths in the fitness of marine fish is particularly difficult. The parasitic species infecting the visceras, skeletal musculature and peritoneal cavity of fish are in the majority metacercariae, metacestodes and nematode larvae (Williams \& Jones, 1994). In the larval stages attached to the epithelium of the digestive tract mucose it is possible to establish a direct relationship between the type of lesion and the anatomical structure of the attachment organ (McVicar, 1972; Borucinska \& Caira, 1993).

A previous research has demonstrated that Porichthys porosissimus (Valenciennes, 1837) hosts at least two larval morphotypes of tetraphyllideans in Bahía Blanca Estuary, Argentina, which have been arbitrarily designated as Scolex pleuronectis types I and II (Tanzola et al., 1997). In view of the above, this study aims at i) determining the localization sites of the larval type I in the digestive tract mucose of $P$. porosissimus; ii) describing the anatomical and pathological characteristics of the larval lesions; and iii) evaluating the potential effect of parasite-infection intensity on the host body condition.

\section{Material and Methods}

This study was carried out on 73 individuals of $P$. porosissimus which were captured using gill nets in the outer area of Bahía Blanca Estuary $\left(38^{\circ} 45^{\prime} \mathrm{S} 62^{\circ} 15^{\prime} \mathrm{O}\right)$. Total length of each fish was registered with an accuracy of $1 \mathrm{~mm}$, and total weight was determined. After exposure of the body cavity, the digestive tract was arbitrarily divided in three portions of different length, namely an anterior portion having very thickened and melanized walls; an intermediate, partially melanized portion having very thin walls; and a posterior, slightly pigmented portion having thin walls. The content of each of these portions was separated in Petri dishes. Parasite identification and count were carried out on them by examining the digestive tract mucose with a thin brush.

The population estimators of parasite prevalence, abundance and intensity of infection (means and ranges) in each portion were calculated according to Bush et al. (1997) and 

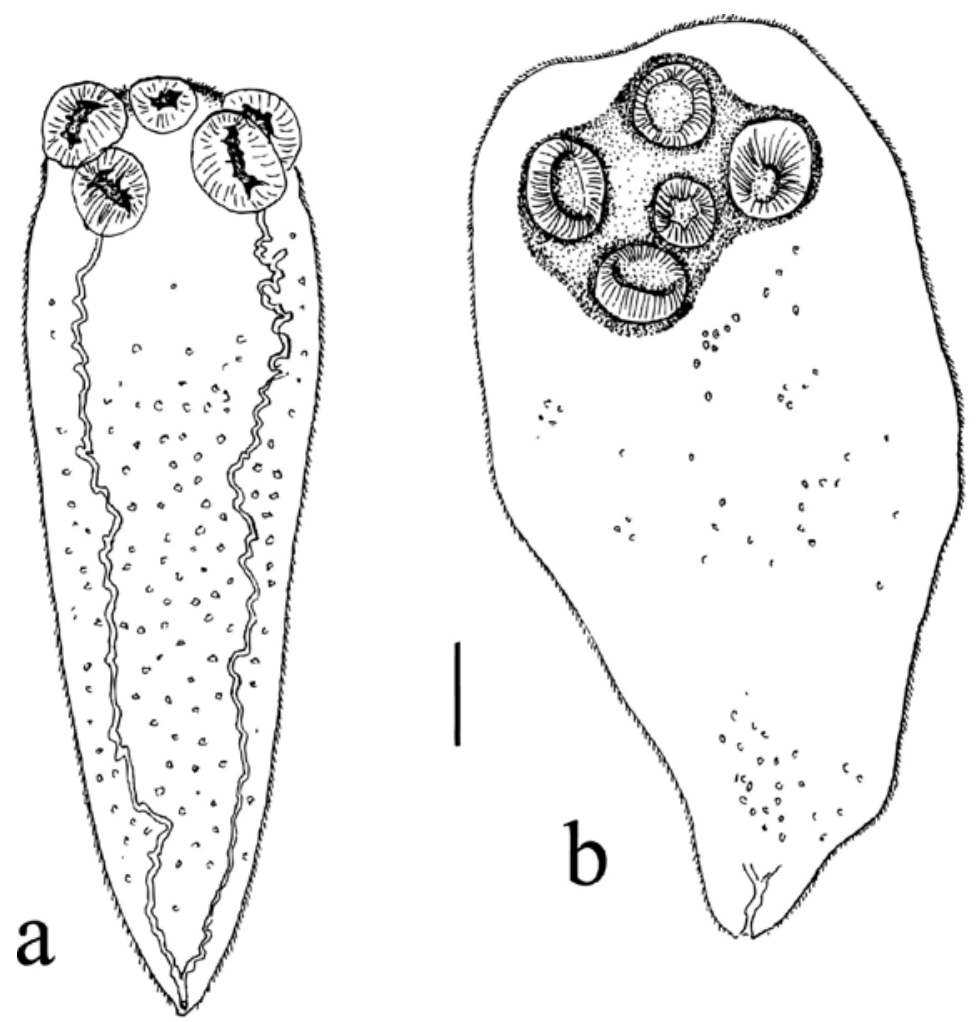

Fig. 1. Tetraphyllidean larvae (schematic) of the Scolex group- a: evaginated; b: invaginated (scale-bar=0.2 mm)

the prevalence confidence interval $(95 \%)$ was calculated following Morales \& Pino (1987).

Parasite intensities in the above-mentioned portions were compared using the non-parametric Mann-Whitney U test. The relationship between the condition factor (K coefficient $=$ total weight $\mathrm{x}$ length ${ }^{-3} \mathrm{x}$ 100) and larval intensity was estimated using Spearman's rank correlation coefficient. The comparison between hepatosomatic index and parasite intensity was evaluated by means of One Factor Anova test.

The morphometric study was carried out on 30 larvae which were relaxed and fixed in hot physiological solution and conserved in $5 \%$ formalin. Measurements corresponding to larval microanatomy are expressed in $\mathrm{mm}$ and mean and range values are in parentheses.

Ten individuals of $P$. porosissimus were dissected for the histopathological analysis. The material was obtained from live fish maintained in an acquarium and sacrified with an overdosis of benzocaine $(0.4 \mathrm{~g} / \mathrm{l})$. Immediately postmortem sections of the digestive tract were fixed in Bouin liquid and processed for histological and pathological studies. Routine histological methods were followed and $5 \mu$ wide cuts were obtained. The staining methods used in this study include Haematoxylin and Eosin, Masson's Trichrome, Periodic acid-Schiff (PAS), and Alcian Blue (pH 2.5 and 1.0)

\section{Results}

Description of the parasite

The larvae of the cestodes found have a tegument covered by microtriches. Their total length is $1.8(1.25-2.02)$ and their maximum width is $0.447(0.324-0.550)$. A light constriction differentiates the scolex from the body. The scolex is occasionally found invaginated (Figs.1a and b). The attachment organ is composed of four unilocular acetabula which are $0.128(0.098-0.200)$ in diameter and an apical ventose which is $0.097(0.072-0.150)$ in diameter. No accesory ventoses are observed. The parenchyma is densely charged by calcareous bodies. In the in toto samples it can be observed by transparency that the route of the longitudinal collector conducts of the excretory system ends in a small posterior blister.

\section{Infection site}

Porichthys porosissimus has a rectilinium-type digestive tract (sligthly bent), which is relatively short and devoid of pyloric caeca. There is no clear demarcation between the cardiac and pyloric regions as it is regularly observed in the stomach of the majority of teleosts. The mucose of the first portion of the digestive tract is macroscopically different from the mid and posterior portions, such difference lies in the presence of a wide and sinuous folding which are remarkably thinner in the latter portions. The wall of the digestive tract is formed by a cylindrical epithelium pseudostratified with mucosecretory PAS positive cells and Alcian Blue positive in a different degree of maturation (Fig. 2). Eosinophilic cells associated to the basal epithelium are also observed.

\section{Histopathology}

The mid portion of the digestive tract showed the highest 


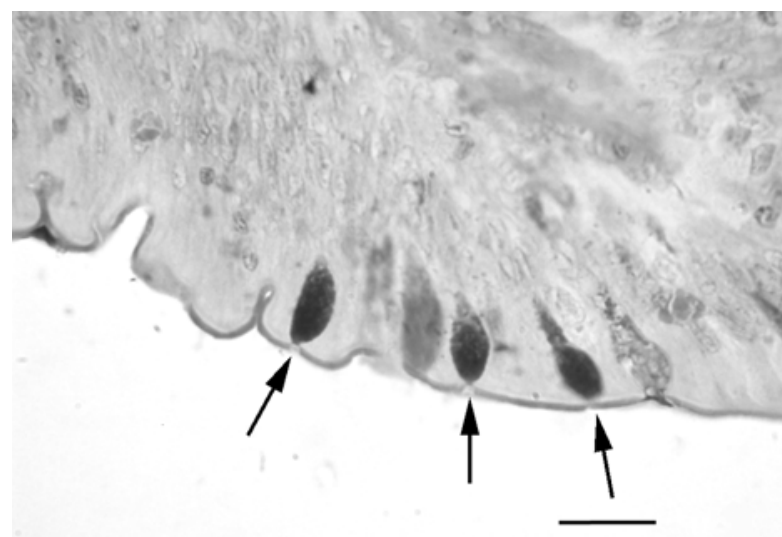

Fig. 2. Histological section of the intestinal mucose of the host, $P$. porosissimus, showing several mucosecretory cells (arrows) (PAS + Alcian Blue; scale-bar $=0.01 \mathrm{~mm}$ ) vellosities. In some areas of the mid portion of the digestive tract with high parasitic charges, two thirds of such spaces were occupied by either one or two larvae. In some cases, the size of the parasites exceeded the height of the mucose vellosities (Fig. 3).

A compressed atrophy of the cells with a marked lowering and also the disappearance of the epithelial layer were observed in the area of contact between the epithelium and the parasite. Groups of lining cells were found fully engulfed in the cavity of suckers (Fig. 4). No lesions, infiltrations or intense degenerative changes were observed in areas below the epithelium. The eosinophilic cells of the mucose were found indistinctively either in parasitized portions or in areas not affected by larvae and they seemed not to be related to the colonization of the lumen by these helminths.

Table 1. Population estimators of cercoid larvae according to the portion of the digestive tract considered

\begin{tabular}{cccc}
\hline Estimator & Portion I & Portion II & Portion III \\
\hline Prevalence (\%) & $50.68 \pm 0.11$ & $98.63 \pm 0.03$ & $67.12 \pm 0.11$ \\
Abundance & $8.17(0-50)$ & $40.73(0-50)$ & $8.03(0-50)$ \\
Intensity & $16.13(1-50)$ & $41.30(1-50)$ & $11.95(1-50)$ \\
\hline
\end{tabular}

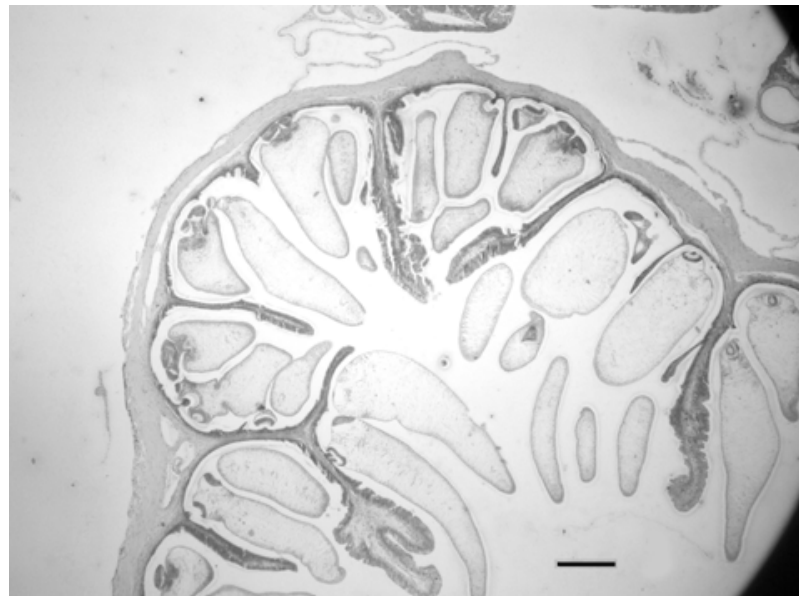

Fig. 3. Transverse section of the intestine of the host densely parasitized by Scolex larvae (Haematoxylin \& Eosin; scale-bar $=0.2 \mathrm{~mm}$ )

values of prevalence and infection intensity (Table 1). As to infection intensity in particular, this portion also evidenced highly significant differences with respect to the first and the third portions $(\mathrm{U}=512, \mathrm{p}=0.00$ and $\mathrm{U}=$ $502.5, \mathrm{p}=0.00$, respectively). However, the first and the third portion revealed no differences between each other with respect to this variable $(\mathrm{U}=2392.5, \mathrm{p}=0.27)$. The $\mathrm{K}$ coefficient of the fishes was significantly affected by infection intensity $\left(r_{s}=-0.29, p=0.013\right)$, thus indicating an adverse effect on the growth and physical condition of the host.

Cestode larvae were found free in the lumen, either moving among the foldings of the mucose or strongly adhered, with their acetabula and apical ventose, to neighboring

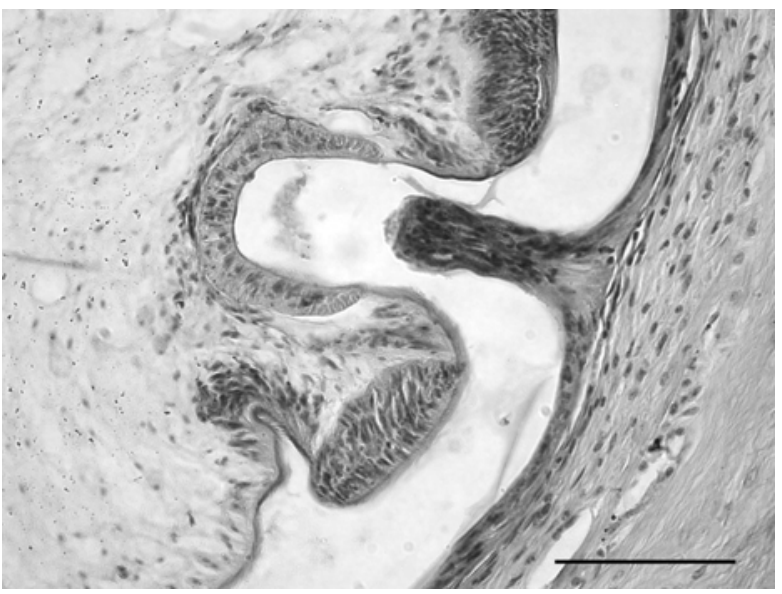

Fig. 4. Portion of epithelial mucose of the host fully engulfed by the apical sucker of Scolex larvae. Note the drastic lowering and atrophy of the epithelial layer surrounding the site of attachment (Masson's Trichrome; scale-bar $=0.05 \mathrm{~mm}$ )

\section{Discussion}

The larval stages recorded in the present study coincide with Dollfus' description (1936) of Scolex de Bavay, the latter being the name used to cite for the first time these larval stages in the digestive tract of Urophycis brasiliensis (Szidat, 1960) from Mar Argentino and later in Parona signata (Szidat, 1969). Different cestode larvae under the name Scolex polymorphus (Sardella \& Timi, 1995; Sardella et al., 1998; Timi, 2003; Timi \& Poulin, 2003; Timi et al., 2005) and Scolex pleuronectis (Tanzola et al, 1997; Tanzola \& Guagliardo, 2000) and belonging to the order Tetraphyllidea were found parasitizing fish in Mar Argen- 
tino. From a nomenclatural point of view, these names are indicative of collective groups, i.e. they are conventional taxonomical groups which are regularly treated as names of generic level and they include both the author and date. They need not be accompanied by a type species fixation and do not compete in priority with other genus-group names (articles 10, 13, 23, and 42 of the International Code of Zoological Nomenclature [ICZN], 1999). Originally, the collective group Scolex (Muëller, 1787) has been indistinctively cited in the literature to designate parenchymatous larvae of similar morphology although belonging to different taxons, thus leading to confusion as well as conflicting conclusions. In an attempt to put order within terminology, during the Third International Workshop for Tapeworm Systematics (held in Sofia, Bulgary, July 20 $24,1999)$ it was agreed to use "plerocercoid" to designate larvae with invaginated scolex and lacking a primary lacuna. On the other hand, alacunate larvae with an invaginated scolex should be categorized as merocercoid (Chervy, 2002). However, Rocka (2003) claimed that the evaginated or invaginated state of the attachment organ of different larval forms could be the consequence of the isolation and preservation process of parasites. In view of this, Rocka (2003) decided to use the generic term "cercoid" to designate the parenchymatous larvae whose scolex can be found either evaginated and attached to the intestinal mucose or in the process of invagination. The names "plerocercoid" sensu Chervy (2002) or "cercoid" sensu Rocka (2003) can be used to designate the larvae recorded in the present study. Likewise, they are similar to morphotype 4 of the metacestodes analyzed by Chambers et al. (2000).

Little is known to date on the effects of larval cestodes on the digestive tract mucose of fish. Paperna \& Overstreet (1981) observed that young mullets (Mugil spp.) in acquaria with high parasitic charges of Scolex polymorphus in the intestine stopped feeding themselves and therefore died. De Lima et al. (1997) described lesions associated to Scolex pleuronectis in the form of pseudocysts in the extremes of piloric caeca of Sardinella brasiliensis on the coasts of Rio de Janeiro, Brazil. These lesions were characterized by fibrosclerosis and widening of the connective tissue of the submucose, thus producing caecal stenosis. Both a slight mononuclear infiltration and eosinophilic cells completed the inflammatory process. Meyers (1978) also described similar dilatations in the biliary ducts in the liver of Cynoscion regalis which were produced by larvae of the Scolex group.

Radhakrishnan et al. (1984) observed minor erosive lesions in the mucose of the digestive caeca of Trichiurus lepturus L. as well as a marked decrease in the weight of the liver and anaemia of the macrocytic type but with no signs of haemorrage or inflammatory reaction in the submucose.

Douellou et al. (1987) claimed that S. pleuronectis is not only the most common but also the most abundant parasite in the anterior intestine and piloric caeca of Arnoglossus laterna which belongs to the family Bothidae (Walbaum,
1792). They observed that in this species high larval intensities of infection produce an alteration in the leukocite formula with an increase in the circulating thrombocytes and progranulocytes (immature neutrophills). They also observed a marked decrease in the percentual hepatosomatic index. Nonetheless, in the present study this parameter was not found affected by the parasitic charge of larvae of the Scolex group ( $F=1.12 ; \mathrm{p}=0.29)$.

Studies carried out on fish affected by adult cestodes demonstrate that the tissular damage in the digestive tract is more serious than that observed in infections induced by larvae. Ulcerations, haemorraghes and deep destruction of the digestive wall fully perforating it as well as atrophy, hypertrophy and compression of the mucose have been reported (Satpute \& Agarwal, 1974, Morley \& Hoole, 1995, Eiras et al. 1986). The absorption of proteins, fat and carbohydrates therefore diminishes affecting both the weight and size of the host and reducing the commercial value of the fishery product (Vazquez Núñez et al. 2004). The mucose cells of the epithelium are involved in different physiological processes which favor the efficiency of the digestive process, promote the absorption of macromolecules, behave as buffer of intestinal fluids, and prevent proteolytic damage from occurring in the epithelium (Arellano et al., 1999). They also behave as a primary barrier against pathogenic agents (Fernández et al., 2002). In the present study it was observed that the mucose cells of $P$. porosissimus evidenced staining features similar to those observed by Arellano \& Sarasquete (2005), i.e. a basal nucleus and a dense aggregation of mucin granules, which, after being released by exocitosis, are combined with water to form a mucose gel. As a consequence, when they are stained with PAS and Alcian Blue they are intensely stained showing an abundant production of mucus by the epithelium. However, the decrease in the number of such cells around the larval attachment site was significant. When alterations are produced in the epithelium such as compressive atrophy, destruction of the epithelium and vulnerability to the primary barrier, the susceptibility of the organism to the attack of pathogenic agents increases and the digestive process is affected. As a result, the absorption and assimilation of nutrients diminish, thus affecting the normal development of the host.

In the present study, the parasitic density of the tetraphyllidean larvae was high, a phenomenon which meant a serious epithelial compromise. In addition, their localization within intestinal vellosities was indicative of a potential damage in a key area of cellular renewal and change. The marked difference in intensity observed in the second digestive portion seems to indicate that this portion is the area of maximum availability of nutrients, thus becoming the site mostly exploited by larvae for colonizing and establishing.

On account of the fact that $100 \%$ prevalence was registered in the individuals analyzed in the present study, there were no non-infected individuals to be used as controls for comparative purposes with respect to K. Nevertheless, 15 hosts with a mean intensity of infection of $15(1-31)$ 
larvae were categorized as with low infection and 15 hosts with an intensity higher than 100 larvae were considered to be highly infected. The differences in the media $\mathrm{K}$ of both groups of fish were highly significant $(\mathrm{F}=10.41 ; \mathrm{p}=$ $0.003)$, with higher values within the low-infection group. These findings are indicative of an adverse effect on the body condition of fish as a result of the deterioration in the absorption mechanism of the intestinal mucose.

\section{Acknowledgements}

Authors are grateful to Messrs Domingo Caserma and Pablo Bustos for capturing the fish analyzed in the present study and to Translator Viviana Soler for translating this paper from Spanish into English. Financial support from the General Secretariat of Science and Technology (PGI 24/B130) and National Agency for the Promotion of Science and Technology (ANPCYT, PICT N $N^{\circ}$ 20438), Universidad Nacional del Sur, Bahía Blanca, Argentina is also greatly acknowledged.

\section{References}

Arellano López, J., Sarasquete Reiriz, C. (2005): Atlas Histológico del lenguado senegalés. Consejo Superior de Investigaciones Científicas. Madrid.

Arellano López, J., Dimis, M. T., SArasquete, C. (1999): Histomorphological and histochemical characteristics of the intestine of the Senegal sole, Solea senegalensis. Eur. J. Histochem., 43(2): 121 - 133

BorUCINSKA, J., CAIRA, J. (1993): A comparison of mode of attachment and histopathogenicity of four tapeworm species representing two orders infecting the spiral intestine of the nurse shark, Ginglymostoma cirratum. J. Parasitol., 79(2): $238-246$

Bush, A. O., Lafferty, K. D., Lotz, J. M., Shostak, A. W. (1997): Parasitology meets ecology on its own terms: Margolis et al. revisited. J. Parasitol., 83(4): 575 - 583

Chambers, C. B., CribB T. H., Jones, M. (2000): Tetraphyllidean metacestodes of teleosts of the Great Barrier Reef, and the use of in vitro cultivation to identify them. Folia Parasitol., 47: 285 - 292

CHERVY, L. (2002): The terminology of larval cestodes or metacestodes. Systematic Parasitol., 52: 1 - 33

De Lima, F., Sao-Clemente, S. De., Mesquita, E. (1997): Caecal pseudocyst associated with Scolex Pleuronectis parasitism in the Brazilian sardine (Sardinella brasiliensis). Parasitología al día 21(1 - 2): 58 - 60

Dollfus, P. PH. (1936): [Cestodes des] Invertébrés marins et thalassoïdes. In JoyeuX, CH. AND BAER, J. G. (Eds): Cestodes. Faune de France, T. XXX. Paris. P. 508 - 509, Fig. $541-569$ B

Douellou, L., Bastide-Guillaume, C., Romestand, B., TRILlERS, J.-P. (1987): Les parasites D'Arnoglossus laterna (Walbaum, 1792), Bothiidae, dans le Golfe du Lion (côte Francaiçe de la Méditerranée) et leur influence sur les formules leucocytaires des poissons hôtes. Rev. Trav. Inst. Pêches Marit., 49 (1 et 2): 25 - 34
Eiras, J. C., Rego, A. A., Pavanelli, G. C. (1986). Histopathology in Paulicea luetkeni (Pisces: Pimelodidae) resulting from infection with Megathylacus brooksi and Javella glanidicephalus (Cestoda: Proteocephalidae). J. Fish. Biol., 28: 359 - 365

FERnÁNDEZ, A. B., RuIZ, I., DE BLAS, I. (2002): El sistema inmune de los teleósteos (II): Respuesta inmune inespecífica. Rev. Aquatic, 17: 1 - 9

INTERNATIONAL COMMISSION ON ZOOLOGICAL NOMENCLATURE (1999): International Code of Zoological Nomenclature. Fourth Edition. The International Trust for Zoological Nomenclature c/o The Natural History Museum-Cromwel Road- London SW7 5BD-UK.

MCVICAR, A. H. (1972): The ultrastructure of the parasitehost of three tetraphyllidean tapeworms of the elasmobranch Raja naevus. Parasitology, 65: 77 - 88

Morales G., Pino DE Morales, L. (1987): Parasitología cuantitativa. Fundación Fondo Ed. Acta Científica Venezolana. Caracas.

MEYers, T. R. (1978): Prevalence of fish parasitism in Raritan bay, New Jersey. Proc. Helminth. Soc. Washington 45: $120-128$.

Morley, N. J., HoOle, D. (1995): Ultrastructural studies on the host-parasite interface between Khawia sinensis (Cestoda: Caryophyllidea) and carp Cyprinus carpio. Dis. Aquat. Org., 23: 93 - 99

MUËLLER, O. F. (1787): Verzeichniss der bisher entdeckten Eingeweidewürmer der Thiere, in welchen sie gefunden wurden, und besten Schriften die dieselben erwähnen. Naturforscher (Halle), 22: 33 - 86

PAPERNA, I., Overstreet, R. (1981): Parasites and diseases of mullets (Mugilidae). In O. H. OREN (Ed.). Aquaculture of Grey Mullets. Cambridge Univ. Press.

RADHAKRISHNAN, S., NAIR, N., BALASUBRAMANIAN, N. (1984): Nature of infection of Trichiurus lepturus Linnaeus (Pisces: Trichiuridae) by Scolex pleuronectis Mueller (Cestoda: Tetraphyllidea). Arch. Hydrobiol., 99(2): $254-$ 267.

RockA, A. (2003): Cestodes of the Antarctic fishes. Pol. Polar Res., 24(3-4): 261 - 276

RockA, A. (2006): Helminth of Antarctic fishes: life cycle biology, specificity and geographical distribution. Acta Parasitol., 51(1): 26 - 35

SARDElla, N. H., TIMI, J. T. (1995): Parasite communities of Merluccius hubbsi from the Argentinian - Uruguayan common fishing zone. Fish. Res., 27(96): $81-88$

SARdella, N. H., Avendaño, M. F., Timi, J. T. (1998): Parasite communites of Genypterus blacodes and G. brasiliensis (Pisces: Ophidiidae) from Argentina. Helminthologia, 35(4): 209 - 218

SATPUTE, L. R., AgARWAL, S. M. (1974): "Diverticulosis" of the fish duodenum infested with cestodes. Indian J. Exp Biol., 12(4): $373-375$

SzIDAT, L. (1960): La parasitofauna como ciencia auxiliar para develar problemas hidrobiológicos, zoogeográficos y geofísicos del Atlántico Sud. Book to pay homage to Dr. Eduardo Caballero and Caballero.

SzIDAT, L. (1969): Los parásitos de la "palometa" Parona 
signata (Jeyns, 1842) Berg, 1895, y su aplicación a problemas zoogeográficos del Atlántico Sur. Neotropica, 15(48): 125 - 131

TAnZOLA, D., Guagliardo, S. (2000): Helminth fauna of the Argentine conger, Conger orbignyanus (Pisces: Anguilliformes). Helminthologia, 37(4): $229-232$

Tanzola, R. D., Guagliardo, S. E., Brízzola, S. M., ArIAS, M. V. (1997): Helminth fauna of Porichthys porosissimus (Pisces: Batrachoidiformes) in the estuary of Bahía Blanca Argentina. Helminthologia, 34(4): 221 - 227 Timi, J., Poulin, R. (2003): Parasite community structure within and across host populations of marine pelagic fish: how repeatable is it? Int. J. Parasitol., 33: 1353 - 1362

TIMI, J. (2003): Parasites of Argentine anchovy in the south-west Atlantic: latitudinal patterns and their use for discrimination of host populations. J. Fish Biol., 63: $90-$ 107

Timi, J., LuQue, J., SARdella, N. (2005): Parasites of Cynoscion guatucupa along South American Atlantic coast: evidence for stock discrimination. J. Fish Biol., 67: $1603-1618$

VAZQUeZ NuÑEZ, R., RAMIREZ LEZAMA, J., OSORIO Sarabi, D., Chavez Soriano, L.A., Constantino CASAS, F. (2004): Lesions caused by helminths of the digestive tract in estuarine fish from the Tres Palos Lagoon, Guerrero, Mexico. Vet. Mex., 35 (4): 369 - 378 WARDle, R. A., MCLeOD, J. A. (1952): The zoology of tapeworms. New York: Hafner Publishing Company.

Williams, H., Jones, A. (1994): Parasitic Worms of Fish. Taylor \& Francis. Ltd., London 